\title{
ROLE OF PARENTS IN THE SUCCESS OF CHILDREN AUTISM
}

\author{
Merri Sri Hartati, Hardiansyah \\ Universitas Muhammadiyah Bengkulu, Sekolah Langit Biru Bengkulu \\ E-mail: merrisrihartatiqie@gmail.com, banghardibengkulu@gmail.com
}

\begin{abstract}
This study aimed to explain the role of parents in accompanied autism children. Research conducted in this study was qualitative with the type of case study. The selection of subjects was based on consideration of being a child with the category of autism, graduated from an inclusive school, and being accepted as a student through a regular test track. The methods used in the study were interviews, observation, and documentation. The results showed that children have a decisive role towards successful children, and helped in supported children, tried as much as possible with therapy, analyzed, and encouraged the talents and interested of children. A suggestion from the findings of this study is that there is a need for individual classes for parents about parenting education for autism children so that parents can help autism children find their talents.
\end{abstract}

Keywords: autism, parental role, successful children.

\section{INTRODUCTION}

Autism spectrum disorder (ADS) is a severe developmental disorder that interferes with the ability to communicate and interact. Autism spectrum disorders affect the nervous system. In Indonesia, there are more than 150 cases of children with autism sentences per year. ${ }^{1}$ Treatment can help this disease but only to reduce the levels because it cannot be cured. Autism is a chronic developmental disorder and can last a lifetime. Boys are 4 times more likely to have autism² ${ }^{2}$

We are fully aware that God created every human being with the best of creation, as well as children who are convicted of autism. FA is one of the children with autism syndrome who is now a teenager and registered as a student at the Bengkulu State Islamic Institute (IAIN) Academic Year (A.Y) 2019/2020, an achievement worthy of being accepted as a student through the regular test. This success, of course, cannot be separated from the role of the two parents from the FA, as stated by Sarasvati that

\footnotetext{
${ }^{1}$ Autism. Downloaded at September, $1^{\text {st }} 2019$ retrieved from URL https://g.co/kgs/ozU3T2.

2 Redaksi Halodoc, “Autisme”. Downloaded at September, 4 ${ }^{\text {th }} 2019$, retrieved from URL https://www.halodoc.com 
parents can become reliable mentors and educators as long as parents want to learn, try and never give up. ${ }^{3}$

The influence of the role of parents is essential for the development of ASD children as Farida's research ${ }^{4}$ shows that the role of the family in helping the growth and development of autistic children is possible in the home environment and communication disorders and social abilities in autistic children can be assisted with mother's guidance. Islam teaches every adherent, that the purpose of human creation is none other than to worship God as his firm in the Qur'an Surah Adz Dzariyat verse 56 and know the power of God in his Al Qur'an Surah Ath Thalaq verse 12.

\section{RESEARCH METHODS}

This research was qualitative research with a case studied method aimed to found what were the forms and effects of the role of parents on the success of children with autism in their growth and development into adolescents. This research was conducted in August 2019. The research subjects were Children with Special Needs with criteria: (1) children with autism or autism syndrome, (2) having complete parents, (3) receive formal education, (4) pass the new admissions selection test, and (5) in general, physical appearance does not indicate children with autism syndrome. Based on the characteristics set, the researcher got one subject that met these criteria, namely Ananda FA. The research instrument used was the observation sheet and interviewed. The data obtained were then analyzed descriptively.

\section{RESULT AND DISCUSSION}

Autism had the following symptoms: behavioral: repetitive movements, inappropriate social interactions, poor eye contact, self-harm, repeated repetition of words or actions, implant behavior, or compulsive behavior. During their development, autism suffered would experience learning disabilities or delayed speech. Lubis and

\footnotetext{
3 Sarasvati, Meniti Pelangi (Perjuangan Seorang Ibu yang Tak Kenal Menyerah dalam Membimbing Putranya Keluar dari Belenggu ADHD dan Autisme), (Jakarta: PT Elex Media Komputindo, 2004), p. 67.

4 Farida, "Bimbingan Keluarga Dalam Membantu Anak Autis (Kehebatan Motif Keibuan)" Jurnal Bimbingan Konseling Islam 6, no. 1, Juni 2015: 85-86.
} 
Suwandi $^{5}$ outlined Autism Spectrum Disorder (ASD) or known as pervasive developmental disorders, was a group of delayed and deviations in the development of social skills, language communication, and behavior.

Autism is a developmental disorder that was reasonably complex, covering almost all aspects of child development so that this disorder provides a broad and severe influence in depth. Communication delayed impaired play, language, behavior, disturbance of feelings and emotions, social interaction, social feelings, and disturbances in sensory feelings.

Autism would experience difficulty in paid attention or intense interested in certain things, experiencing depression and unconscious emotion in others, anxiety, and sensitivity to sound. Children affected by this disorder would have difficulty making eye contact and unable to express what was in their minds in verbal language to others. ${ }^{6}$ FA's father said:

" Our son could not speak until three years old. He was not same with other children who spoke and ran fluently."7

According to Pottie et al. ${ }^{8}$, those parents who had autistic children have more stressful experiences. These various emotional upheavals arise in the parents even to the point of disrupting their physical condition, and the level of the disorder is related to the extent to which parents have resilience or resilience to the trials faced ${ }^{9}$. AK (FA's father) said that:

"When we learned of our late arrival, we began to consult the condition of our child to the pediatrician, and we found that our child had autism, it was very human, we felt sad always to ask what sin we had to endure. However, this did not last long, my wife and I agreed to provide treatment, and my wife applied for leave for 3 months to accompany my child to therapy in the city of Medan even if within 3 months there were no significant changes, we had agreed that my wife would resign and focus on matching FA growth and development. The city of Medan was chosen as a place of therapy because the distance from the city of Bengkulu is not too far away, and there are still many families so it is possible for easy access and shelter during the therapy ".

\footnotetext{
${ }^{5}$ Fauziah Lubis \& Johns Fatriyadi Suwandi, "Paparan Prenatal Valproat dan Autism Spectrum Disorder ( ASD ) pada Anak" Medical Journal of Lampung University 5, no. 3 (2016): 85-90.

${ }^{6}$ Muniroh, S.M. "Dinamika Resliensi Orangtua Anak Autis" Jurnal Penelitian 7, no. 2 (2012). https://doi.org/10.28918/jupe.v7i2.112.

${ }^{7}$ Interviewed with AK, July, $31^{\text {st }} 2019$.

${ }^{8}$ Pottie, C. G \& Lopez, S.J. Positive Pschology: The Scientifis Practical Exploration of Human Strenghts. (London: Sage Publication, 2007), p. 1.

${ }^{9}$ Ibid., p. 6.
} 
The high levels of resilience possessed by the FA's parents made them stronger and immediately rose from their trials and immediately found the best solution for their baby. Murray stated, "risk factors and protective factors that a person had in dealing with challenging conditions in life. ${ }^{10}$

Families who adapted quickly to the conditions of diagnosis of autism suffered by their children will be able to use their resources to support their child's development. Supporting resources for children with autism, according to Apostelena ${ }^{11}$ could be in the formed of social supporting obtained from relatives and friends as well as community and family system resourced that included the ability of family resilience, these resourced helped families deal with the problems encountered. This is a resource that is owned by the FA family, who continues to strive for goodness in its growth and development.

The effort was carried out as a therapy in a particular therapy place for children with autism syndrome, considering that autism is not a disease but a disorder in the nervous system caused by heredity, and autism is not a symptom of the disease but is a syndrome (a collection of symptoms) social disturbances occur, language skills and caring so that autistic children like living in their world. ${ }^{12}$ The FA's father also explained this condition:

"Children with special needs tend to be angry or angry, and this is because we do not know what they want; instead, they are not able to convey their intentions. So slowly, we began to study and seek assistance to the FA, we were present as parents in the real sense ".

Boham in his research results stated that some of the problems that are generally found in children with autistic disorders are social aspects and communication that are very lacking or slow and repetitive behavior or repetition and this situation can be observed in children such as the child's lack of ability to establish excellent and adequate reciprocal social interactions, lack of eye contact, lack of cheerful or lively

\footnotetext{
${ }^{10}$ Murray, C. "RISK Factors, Protective Factors, Vulnerability, and Resiliensce. A frame Work for Understanding and Supporting the Adult Transition of Youth with High-Incident Disabilities" Journal of Remedial and Special Education 24, $\quad$ no. 1 (2003): 16-26. https://doi.org/10.1177\%2F074193250302400102.

${ }^{11}$ Eunike Apostelina, "Resiliensi Keluarga Pada Keluarga yang Memiliki Anak Autis" Jurnal Penelitian dan Pengukuran Psikologi 1, no. 1, Oktober 2012: 164-175. http://journal.unj.ac.id/unj/index.php/jppp/article/download/347/295.

${ }^{12}$ Lorentius Goa \& Teresia Noiman Derung, "Komunikasi Ekspresi dengan Metode PECS bagi anak Autis" Jurnal Nomosleca 3, no. 2 (2017) http://jurnal.unmer.ac.id/index.php/n/article/view/2037.
} 
facial expressions and movements of limbs that are less targeted, unable to play with peers so that they appear alone or tend to be loners and even cannot empathize or feel what other people feel. ${ }^{13}$

Several treatments can be done in assisting autistic children, namely: anger management, family therapy, applied behavior analysis, behavioral therapy, sensory integrate, animal-assisted therapy, online speech therapy. The FA therapy that is carried out is anger management therapy and parental assistance in providing education

"This therapy bore fruit in the development of FA, at the age of the elementary school, FA was accustomed to read Sirah Nabawi, a thick type of book because there were quite a lot of pages for the book category. The FA has a very high interest in the world of history, more specifically in the history of Islam. "

FA got ABA therapy (applied behavior analysis) from an early age to continued at school age and ends when the FA graduated elementary school. Aba therapy had a significant influenced on the development of FA in terms of socialized and learned in regular schools, as stated by one of the therapists who had assisted the FA:

\footnotetext{
"Ananda FA has received autism therapy, which is the ABA method from an early age, in the past, I had to go back and forth from Bengkulu to Lubuklinggau to conduct therapy, until finally, it continued in Bengkulu. This therapy has a significant impact on making FA conditions conditioned and being able to take lessons in class ".
}

This statement was in line with the results of Hardiani's ${ }^{14}$ This was in line with the results of the studied showed that the method ABA Hardiani a positive impacted on increased the students' social interaction skills. This condition is in line with the results of the study showed that the method ABA Hardiani a positive impact on increasing the students' social interaction skills.

According to Yuwono, ${ }^{15}$ by handling early before the age of 5 years, $40-60 \%$ of children with autism could be enrolled in regular schools, methods for early intervention that can be given to children with autism who experience a disruption in social

${ }^{13}$ Sicillya E Boham, "Pola Komunikasi Orang Tua dengan Anak Autis (Studi pada Orang Tua dari Anak Autis di Sekolah Luar Biasa Agca Center Pumorow Kelurahan Banjer Manado" Acta Diurna Komunikasi 2 , no. 4 https://ejournal.unsrat.ac.id/index.php/actadiurnakomunikasi/article/view/2886/2436.

${ }^{14}$ Ratna Sari Hardiani \& Sisiliana Rahmawati, "Metode ABA (Applied Behaviour Analysis): Kemampuan Bersosialisasi Terhadap Kemampuan Interaksi Sosial Anak Autis" Jurnal Keperawatan Soedirman (The Soedirman Journal of Nursing) 7 , no. 1 (2012): 1-9. http://www.jks.fikes.unsoed.ac.id/index.php/jks/article/view/336/176.

${ }^{15}$ Yuwono, J. Memahami Autistik. (Bandung: Penerbit Alfabeta, 2009). 
interactions, one of them by the ABA period. Handojo ${ }^{16}$ ABA method was a behavioral management method used nonviolent teaching methods, and this method could help autistic children learned necessary social skills such as paid attention, maintaining eye contact, and being able to control behavior.

Apart from the provision of therapy that has begun at an early age since the FA was diagnosed with autism syndrome through elementary school, the most important thing is the acceptance of parents and families of the conditions experienced by the FA. As told by the FA father:

"The main task of human creation is to worship God. Until I later realized and interpreted the verse, my family and I accepted the condition of the FA with all its advantages and disadvantages and only wanted the FA to be a servant who was able to worship God. I do not expect anything grandiose, but Alhamdulillah, the FA can surpass that after the FA has been able to concentrate and sit still, there has begun to be directed according to their interests and talents. Al Quran said in surah Adz Dzariyat: 56 that mean was And I did not create the jinn and humankind except to worship me and Qur'an Surah Al Mu'minun verse 115 that mean hen did you think that we created you uselessly and that to us you would not be returned?"

The ability of the family to accept the conditions of the FA had an impacted on providing the best education for the FA because the FA's parents believed that education was one of the best efforts for his son and as parents also need partners in matching the growth and development of the FA.

"Early childhood and kindergarten children as children of an age where they cannot be ruled and cannot be banned, but they can be taught, educated, and only early childhood and kindergarten teachers can do it, and we as parents are very grateful to FA teachers who have been very patient and try hard to assist the FA "17

The difficulty of autistic children was the inability to concentrate, primarily when studied. The concentration of learning was activated to limit the scope of one's attention to an object of learning material. However, this did not make the FA's parents despair, and they believed that an autistic child was a gift from God and deserved education.

"If God entrusted a child with special needs, then it was a hassle at the beginning, hassle when making the child sit and concentrated, but if he was able to concentrated, 2009).

${ }^{16}$ Handjono, Y. Autisme Pada Anak. (Jakarta: PT Buana Ilmu Populer Kelompok Gramedia,

${ }^{17}$ Dialogue with FA's father, August, 31th 2019. 
the child would become a submissive person, and it will even be very easy for us to knew his talents and our task how to directed them." 18

This acceptance was one form of resilience that has been owned by the FA family. Family resilience needs to be seen as a unified whole. Especially in seeing the various life events that occur so that every family that has an autistic child can be resilient properly. Each family supported each other to be able to adapt finally and had the same goal to give the best both children with special needs for autism who were members of their family. ${ }^{19}$

Besides, FA parents believed that children need to be trusted and trained to be independent in order to be able to solve their problems and take responsibility for themselves and their actions. The FA was not treated as unique; he still had to learn when to face the UN and SPAN PTKIN, as the final notes from the FA father were submitted to researchers as follows:

\begin{abstract}
"School habituation provides answers to children will have an impact on children on the reluctance of students to studied, and they did not study at all until they end up enable to passed the PT because they were unable to complete the PT entranced examination selection test."
\end{abstract}

Then the success of the FA could graduate with the results of their learning was something that was very appreciated by the family.

\title{
CONCLUSION
}

Autism children are a gift from God. The acceptance of the presence of family members with a diagnosis of autism syndrome is a form of resilience and support for the progress of growth, affection, and education given by parents. This acceptance is also to foster self-confidence and independence in children to restore their nature as a servant of God created to worship the Creator. With this acceptance, children with autism also feel that they have a place both in the family and in the full social environment. There is a parenting class to educate parents about autistic children so that they can help parents know the potential and good parenting about autism.

\footnotetext{
${ }^{18}$ Speaking of FA father, August, 31th 2019.

19 Eunike Apostelina, "Resiliensi Keluarga Pada Keluarga yang Memiliki Anak Autis” Jurnal Penelitian dan Pengukuran Psikologi 1, no. 1, Oktober 2012: 164-175. http://journal.unj.ac.id/unj/index.php/jppp/article/download/347/295.
} 


\section{REFERENCES}

Apostelina, Eunike. (2012). "Resiliensi Keluarga Pada Keluarga yang Memiliki Anak Autis" Jurnal Penelitian dan Pengukuran Psikologi 1, no. 1: 164-175. http://journal.unj.ac.id/unj/index.php/jppp/article/download/347/295.

Autism. Downloaded at September, $1^{\text {st }} 2019$ retrieved from URL https://g.co/kgs/ozU3T2.

Boham, Sicillya E. (2013). "Pola Komunikasi Orang Tua dengan Anak Autis (Studi pada Orang Tua dari Anak Autis di Sekolah Luar Biasa Agca Center Pumorow Kelurahan Banjer Manado" Acta Diurna Komunikasi 2, no. 4. https://ejournal.unsrat.ac.id/index.php/actadiurnakomunikasi/article/view/2886/24 $\underline{36}$.

C. G, Pottie \& Lopez, S.J. (2007). Positive Pschology: The Scientifis Practical Exploration of Human Strenghts. London: Sage Publication.

C., Murray. (2003). "RISK Factors, Protective Factors, Vulnerability, and Resiliensce. A frame Work for Understanding and Supporting the Adult Transition of Youth with High-Incident Disabilities" Journal of Remedial and Special Education 24, no. 1: 16-26. https://doi.org/10.1177\%2F074193250302400102.

Farida. (2015). "Bimbingan Keluarga Dalam Membantu Anak Autis (Kehebatan Motif Keibuan)" Jurnal Bimbingan Konseling Islam 6, no. 1: 85-86.

Goa, Lorentius \& Teresia Noiman Derung. (2017). "Komunikasi Ekspresi dengan Metode PECS bagi anak Autis" Jurnal Nomosleca 3, no. 2. http://jurnal.unmer.ac.id/index.php/n/article/view/2037.

Handjono, Y. (2009). Autisme Pada Anak. Jakarta: PT Buana Ilmu Populer Kelompok Gramedia.

Hardiani, Ratna Sari \& Sisiliana Rahmawati. (2012). "Metode ABA (Applied Behaviour Analysis): Kemampuan Bersosialisasi Terhadap Kemampuan Interaksi Sosial Anak Autis" Jurnal Keperawatan Soedirman (The Soedirman Journal of Nursing) 7 , no. $1: \quad 1-9$. http://www.jks.fikes.unsoed.ac.id/index.php/jks/article/view/336/176.

Lubis, Fauziah \& Johns Fatriyadi Suwandi. (2016). "Paparan Prenatal Valproat dan Autism Spectrum Disorder ( ASD ) pada Anak" Medical Journal of Lampung University 5, no. 3: 85-90.

Redaksi Halodoc, “Autisme”. Downloaded at September, $4^{\text {th }} 2019$, retrieved from URL https://www.halodoc.com

Sarasvati. (2004). Meniti Pelangi (Perjuangan Seorang Ibu yang Tak Kenal Menyerah dalam Membimbing Putranya Keluar dari Belenggu ADHD dan Autisme), (Jakarta: PT Elex Media Komputindo). 
Merri Sri Hartati, Hardiansyah

S.M. Muniroh. (2012). "Dinamika Resliensi Orangtua Anak Autis" Jurnal Penelitian 7, no. 2. https://doi.org/10.28918/jupe.v7i2.112.

Yuwono, J. (2009). Memahami Autistik. Bandung: Penerbit Alfabeta. 
